\title{
A Rediscovered Almoravid Qur'ān in the Bavarian State Library, Munich (Cod. arab. 4)
}

\author{
Umberto Bongianino \\ University of Oxford, Oxford, U.K. \\ umberto.bongianino@orinst.ox.ac.uk
}

\begin{abstract}
This article examines and contextualizes a small Quranic manuscript, copied in alAndalus in 533/1138-1139, whose importance has so far gone unrecognized. Among its many interesting features are: its early date; its lavish illumination; its colophon and the information contained therein; its system of notation and textual division; its use of different calligraphic styles, including Maghribī thuluth; and a series of didactic notes written at the beginning and end of the codex. Presented in the appendix is an updated list of the extant Qurāns in Maghribī scripts dated to before 6oo/1203-1204, aimed at encouraging the digitization, publication, and comparative study of this still largely uncharted material. The advancement of scholarship on the arts of the book, the transmission of the Qurān, and the consumption of Quranic manuscripts in the Islamic West depends upon the analysis of these and many other surviving codices and fragments, related to Cod. arab. 4 of the Bavarian State Library and its context of production.
\end{abstract}

\section{Keywords}

Al-Andalus - Almoravids - Maghribī scripts - Qurān - illumination - calligraphy

Cod. arab. $4^{1}$

Among the lesser-known treasures of the Bavarian State Library in Munich is a small Qur'ān, kept under the shelf mark Cod. arab. 4, which once belonged to

1 Submitted on January 6, 2020. Accepted for publication on March 2, $202 \mathrm{O}$. 
the German humanist Johann Albrecht Widmannstetter (1506-1557). ${ }^{2}$ Despite its unassuming appearance, this manuscript represents an essential piece in the complex jigsaw of the arts of the book in the Western Islamic world.

The codex has a roughly square format $(17.3 \times 16 \mathrm{~cm})$ and comprises 130 thin parchment folios sewn into ternions and arranged according to Gregory's law, with the flesh side of each folio always facing the flesh side of the following one. ${ }^{3}$ The left and right margins of each page are scored in dry point, delimiting a written area that measures $11 \times 10.5 \mathrm{~cm}$ and features 23 lines of miniature Maghribī calligraphy. The codex is profusely illuminated with verse dividers and marginal vignettes, and the text of the Qurān is preceded and followed by an impressive set of frontispieces and finispieces. These include four polychrome carpet pages (ff. 2b-3a, 128b-129a), a lavishly ornamented page spread containing the colophon (ff. 127b-128a), and a series of didactic notes written in gold at the beginning and end of the book (ff. 1b-2a, 12gb).

The codex has been variously attributed to the 11th, 12th, 13th, and even 14th century, which is indicative of the still inadequate state of scholarship on the history of Quranic calligraphy and illumination in al-Andalus and the Maghrib. ${ }^{4}$ However, a careful reading of the colophon [fig. 1] gives not only a precise year for the completion of this copy, but also the name of one of the artists involved in its making:

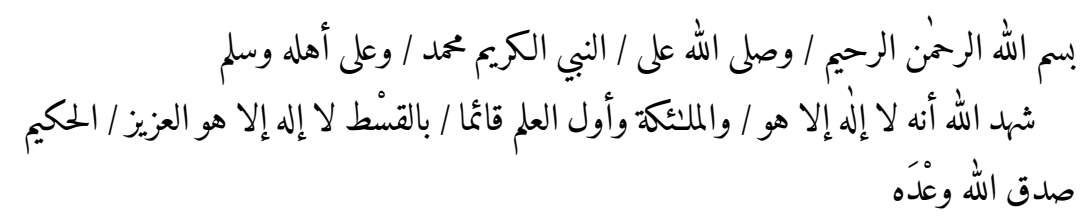

2 The manuscript was first catalogued in Gustav Flügel, "Katalog der arabischen, türkischen, persischen, syrischen und äthiopischen Handschriften aus der Hoff- und Staatsbibliothek in München", Jahrbücher der Literatur 47 (1829), 1-46: 35, no. 137 (80), and subsequently in Joseph Aumer, Die arabischen Handschriften der K. Hof- und Staatsbibliothek in Muenchen (Munich: Palm, 1866), 2. It has also appeared in the following publications: Emil Gratzl, Islamische Bucheinbände des 14. bis 19. Jahrhunderts: Aus den Handschriften der Bayerischen Staatsbibliothek (Leipzig: Hiersemann, 1924), no. 6; Das Buch im Orient. Handschriften und kostbare Drucke aus zwei Jahrtausenden, catalogue of the Munich exhibition, 16.11.19825.2.1983 (Wiesbaden: Reichert, 1982), 125, no. 57; Prachtkorane aus tausend Jahren, catalogue of the Munich exhibition, 7.10-28.11.1998 (Munich: Bayerische Staatsbibliothek, 1998), no. 5 .

3 Between f. 26 and f. 27 two quires are missing, originally containing Q. 5:12-6:77. This lacuna predates the 19th-century foliation of the codex.

4 Gratzl, Islamische Bucheinbände, "beginning of the 14th century"; Das Buch im Orient, "probably 13th-century"; Prachtkorane, "12th-13th centuries". The online catalogue of the Bayerische Staatsbibliothek gives the date "ca. 11th century": https://opacplus.bsb-muenchen.de/title/ BVo35403092 (last accessed: o6.03.2020). 


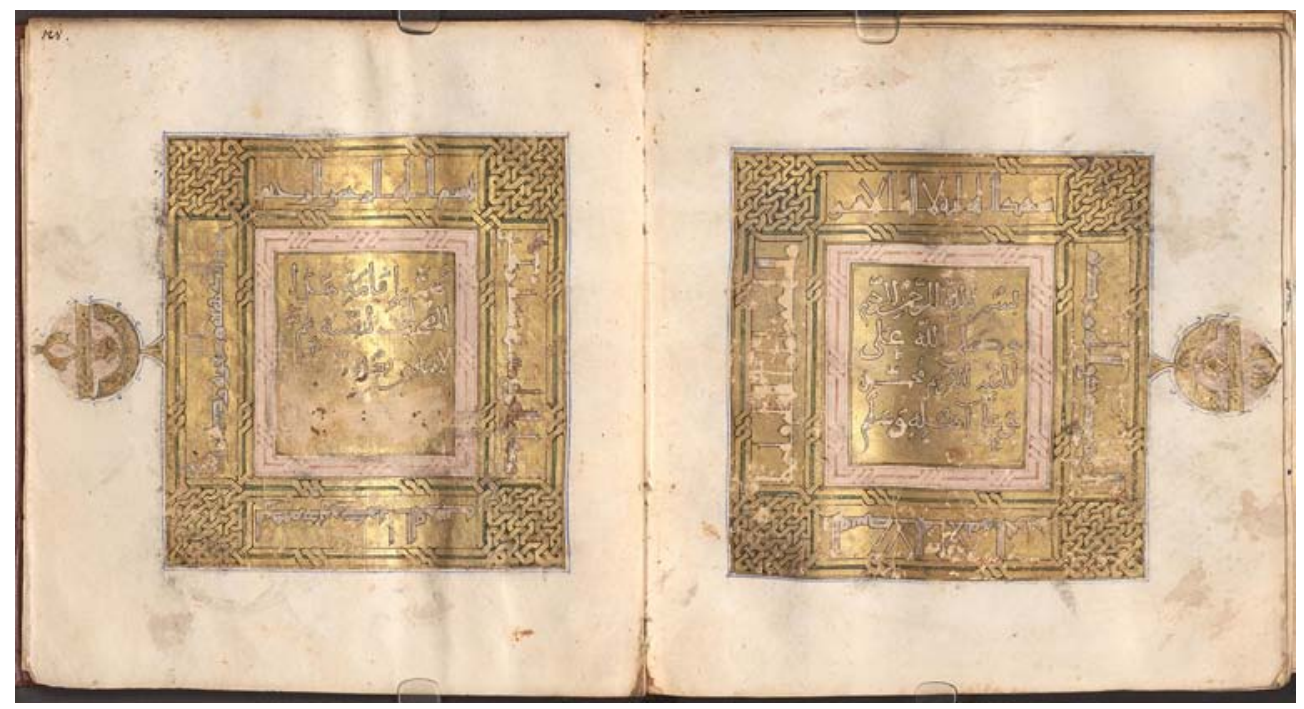

FIGURE 1 Munich, BSB, Cod. arab. 4, ff. 127b-128a. Illuminated colophon with calligraphy in reserve over a leaf-gold background. Maghribī thuluth (centre) and Kufic script (frames)

(C) BAYERISCHE STAATSBIBLIOTHEK

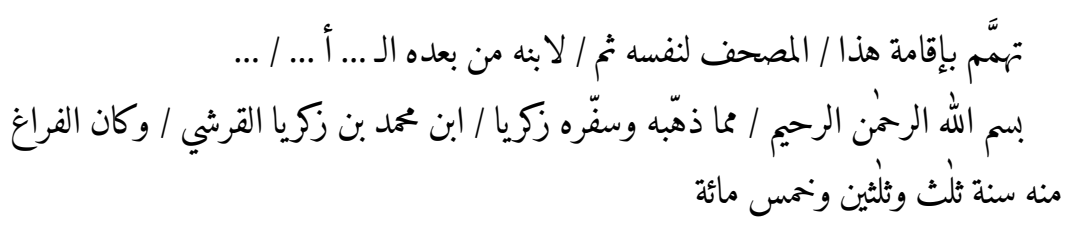

After a series of religious formulae and pious invocations, we learn that the manuscript was copied in 533/1138-1139, and that it was "illuminated and bound (dhahhaba-hu wa-saffara-hu)" by a certain Zakariyā b. Muḥammad b. Zakariyā al-Qurashi. This name, not attested in any of the published sources, must have belonged to an exceptionally skilled artisan if we consider the inventiveness, chromatic richness, and meticulousness of his geometric and calligraphic compositions [fig. 2]. Unfortunately, the codex is no longer bound in its original cover: its current blind-tooled leather binding can be attributed to the $15^{\text {th cen- }}$ tury on the basis of similarities with other Islamic bindings from this period. ${ }^{5}$ While Zakariyā signed and dated his work in the rectangular frame of the colophon, the central panel was originally occupied by the name of the patron and first owner of the manuscript, who "took care of the realisation of this Qur'ān, for himself and for his son after him ...", but this was later scraped off the page in a puzzling act of effacement.

5 Thus Gratzl, Islamische Bucheinbände, no. 6. It is possible that the codex was re-bound in $15^{\text {th- }}$ 


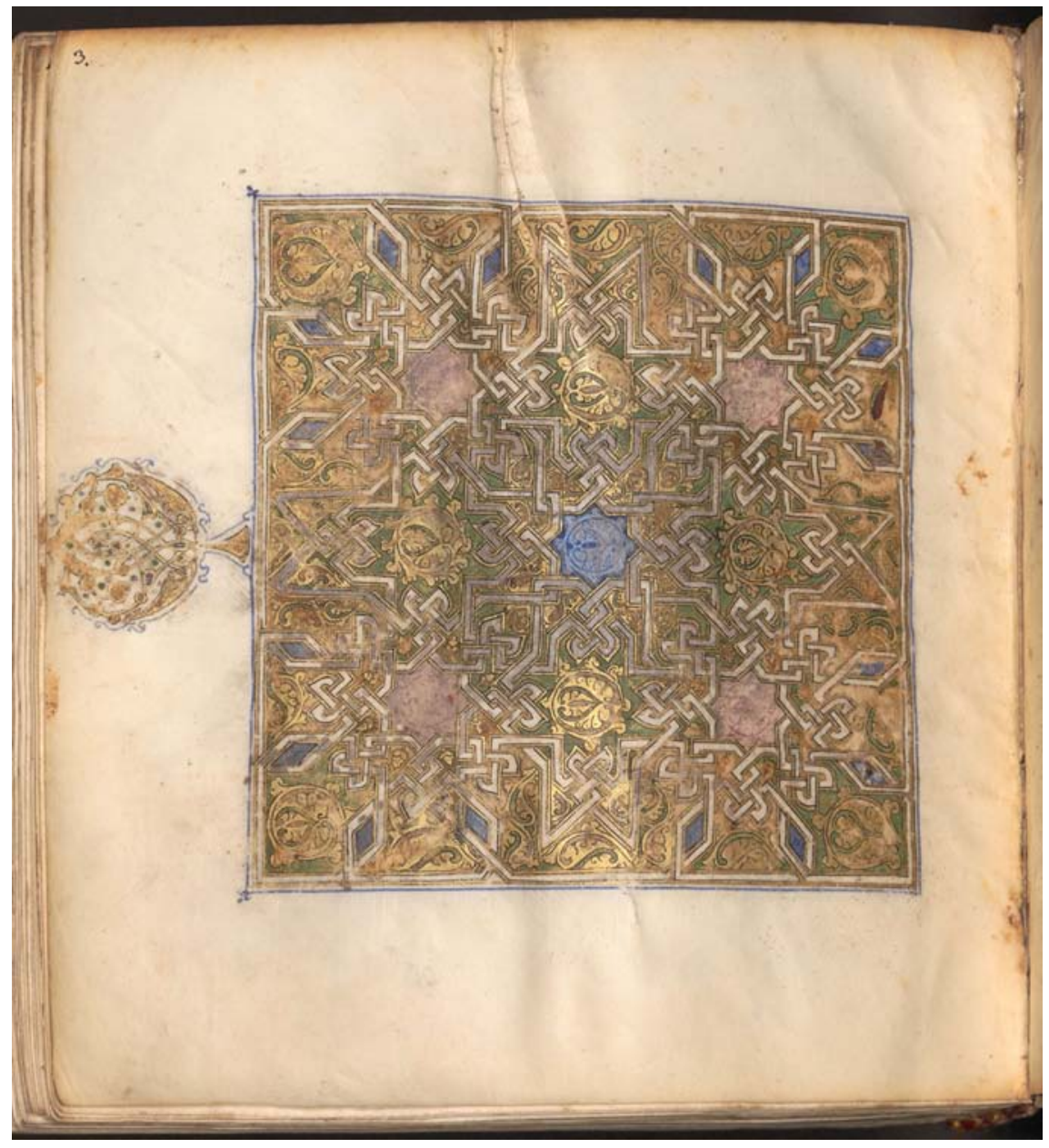

FIGURE 2 Munich, Bs B, Cod. arab. 4, ff. 3a (left), 3 b (right). Geometric frontispiece and beginning of the Qurān (1:1-5) with a calligraphic rendition of the Fätiha in Maghribī thuluth, framed by pious invocation in Kufic

(C) BAYERISCHE STAATSBIBLIOTHEK

It is not unusual to find in the colophons of 12th-century Andalusī Qur'āns references to the patrons for whom they were produced. In Valencia, the calli-

century Tunisia, from where some of Widmannstetter's Arabic manuscripts came to Europe (e.g. Cod. arab. 1). 


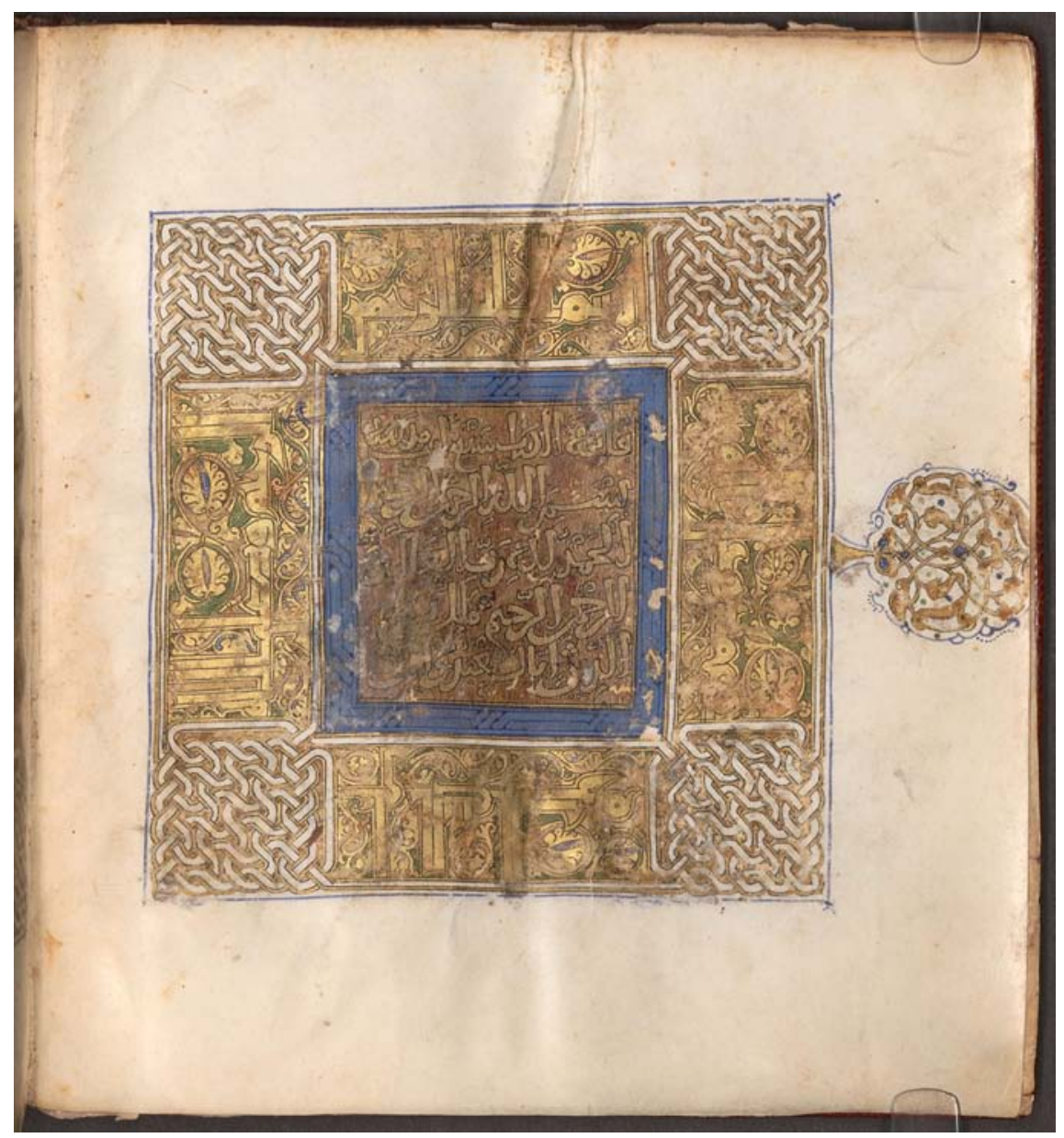

graphers 'Abd Allāh Ibn Ghațtūs (active between 556/116o-558/1163) and Yūsuf Ibn Khaldūn (active in 596/1199-1200) copied Qur'āns of similar size and format for three local notables: Abū Muhammad 'Abd Allāh b. 'Abd al-Raḥmān b. 'Abd Allāh al-Madhhijīi al-Lawshī, called "the most glorious vizier (al-wazìr al-ajall)"; ${ }^{6}$ a certain Yāsīn b. Lub b. Yāsīn; ${ }^{7}$ and Aḥmad b. Muḥammad b. Bīṭash

6 Cairo National Library, Ms. 196 مصحف (18.5 ×17.5 cm), copied by 'Abd Allāh Ibn Ghaț̣̄us in 557/1161-1162, on which see Muhammad b. Sa'īd Sharīî̀, Khuțūṭ al-mașāhif 'ind al-Mashāriqa wa-l-Maghāriba (Algiers, 1982), 259-265; Élisabeth Dandel, "Ibn Ġațūs: une famille de copistes-enlumineurs à Valence (Espagne)", Histoire de l'art 24 (December 1993), 13-24: 15. This member of the Banū Sac̄āa al-Madhhijīi may have served as vizier under Ibn Mardanīsh, who ruled over Murcia and Valencia when this Qurānn was produced.

7 Tunis National Library, Ms. $18791(17.5 \times 16 \mathrm{~cm})$, copied and illuminated by 'Abd Allāh Ibn 
al-Makhzūmī, a member of the Valencian family of the Banū Bìțash (or Bìțish). ${ }^{8}$ A fourth important example of patronage comes from a slightly larger codex dated 599/1203, completed in Marrakesh through the joint efforts of the calligrapher ("nāsikh") Muhammad b. Muḥammad al-Sharīshī and his son-in-law Yūsuf, the illuminator ("al-mudhahhib"). ${ }^{9}$ This is a royal Qur'ān, which, according to its colophon, was produced to celebrate the birth of the Almohad prince Abū Ya'qūb, the son and heir apparent of the caliph al-Nāșir (r. 595/1199$610 / 1213)$.

There is more than one way in which these manuscripts, including the Munich Qurān, refer to their dedicatees and the role they played in their realization. The Qur'ān copied for the prince Abū Ya'qūb features the simple expression "mimmā 'amala-hu [...] li-[...]", translatable as "made by [...] for [...]", and a similar turn of phrase appears in the Qurān dedicated to Ibn Bìtash alMakhzūmī ("kāna kamālu-hu li-[...]", meaning "completed for [...]"). In both these colophons, the calligrapher's name appears before that of the patron, and the patron is not the subject of any verb; in other words, his agency is somewhat downplayed. On the contrary, in the two Qur'āns copied by 'Abd Allāh Ibn Ghatțūs, the patron's name is mentioned before that of the copyist and is introduced as the grammatical subject of the sentence: the vizier Abū Muhammad al-Madhhiji "commanded the realization of this Qur'ān (amara bi-iqāmat hädha al-muṣhaf)", a verb particularly fitting to someone in a position of power, while Yāsīn b. Lub "realized it for himself (aqāma-hu li-nafsi-hi)". This ambiguous expression could be taken to indicate a hands-on involvement, were it not for the immediately following statement that Ibn Ghaț̣ūs "wrote and illuminated it (kataba-hu wa-dhahhaba-hu)". As we have seen, in the Munich Qur'ān the patron's (missing) name is preceded by the curious circumlocution "tahammama bi-iqāmat hādhã al-mușhaf", which I have translated as "he took care

Ghaț̣ūs in 558/1162-1163, on which see Sharīî̄, Khuṭūṭ al-mașāhif, 266-269; Dandel, "Ibn Ġațțūs", 15-16. The dedicatee was apparently the son of a Christian named Lope (or Llop in the Catalan-Valencian dialect, meaning "wolf").

8 Khalili Collection, Ms. QU R.318 $(17 \times 16 \mathrm{~cm})$, copied by Yūsuf b. 'Abd Allāh b. 'Abd al-Wāḥid b. Yūsuf b. Khaldūn, on which see David James, The Master Scribes. Qur'ans of the 1oth to 14th Centuries, The Nasser D. Khalili Collection of Islamic Art, II (London: The Nour Foundation in association with Azimuth Editions and Oxford University Press, 1992), 92-95.

9 Topkapı Palace Library, Ms. R. $33(22.3 \times 18 \mathrm{~cm})$, on which see Fehmi E. Karatay, Topkapı Sarayı Müzesi Kütüphanesi Arapça Yazmalar Kataloğu, vol. I: Kur'an, Kur'an ilimleri, tefsirler (İstanbul: Topkapı Sarayı Müzesi, 1962), I, 83, no. 299; Martin Lings, The Quranic Art of Calligraphy and Illumination (London: World of Islam Festival Trust, 1976), 216-219, pls. 102-103; AlAndalus. The Arts of Islamic Spain, catalogue of the New York exhibition, 1.7.1992-27.9.1992 (New York: Abrams, 1992), 309, no. 79. 
of the realization of this Qur'ann". This is because the fifth form of the verb hamma conveys a sense of attention and solicitude perfectly reflected in the manuscript's extraordinary features, discussed below. ${ }^{10}$

The appearance of the verb aqūma (with its verbal noun iqāma) in the colophons of these three last Quranns suggests that the term was used in connection with patrons and dedicatees, at least in the context of 12th-century Andalusi manuscripts. Supporting evidence comes from the copy of an Andalusī work of Ash'‘arī theology completed in 540/1146-1147, which ends with a colophon stating: "fa-rahima Allāh man aqäma-hu li-nafsi-hiwa-man kataba-hu wa-man qara'a fi-hi", translatable as: "may God have mercy upon [the person] who realized it for himself, and [upon the person] who wrote it, and [upon the person] who read it"."1 Here again, whoever "realized" the manuscript did not actually copy it, but had it copied by someone else: the terminology may appear ambiguous to us, but it was likely not so for a 12th-century Andalusī reader. We are thus left with a tantalizing question: if Zakariyā al-Qurashī simply illuminated and bound the Munich Qurān, and if the patron did not take an active part in its creation, then who was responsible for its calligraphy? The absence of any reference to the act of writing or to the copyist in a colophon that gives the names of both the patron and the illuminator is a unique occurrence in this period, and indeed difficult to rationalize. It is tempting to imagine that the special care with which the patron tended to the creation of this codex, as mentioned in the colophon, meant that he personally copied and vocalized the text of the Qurān, and then entrusted Zakariyā al-Qurashī with its illumination and binding.

While this cannot be proven, it seems reasonable to suggest that Zakariyā did not copy the text of the Munich Qurān: had he done so, he would likely have mentioned it, as was customary. We are thus confronted with a manuscript that, although small, likely resulted from a collaboration between (at least) two individuals, a calligrapher and an illuminator, just like the Quraan dedicated to the prince Abū Ya'qūb. This adds to the extraordinary features of the codex, especially since we know that, in 12th-century al-Andalus, Quranic copyists were also skilled illuminators, perfectly able to see to all aspects of book production. The already mentioned 'Abd Allāh Ibn Ghațțūs and his son Muhammad (d. circa 610/1213-1214), for instance, both signed their work with the expression

10 Reinhart Dozy, Supplément aux dictionnaires arabes (Leiden: Brill, 1881), II, 763.

11 Rabat National Library, Ms. 98 Q (3), on which see Saīd Al-Murābițī, Catalogue des manuscrits arabes conservés à la Bibliothèque Nationale du Royaume du Maroc_Tome VII: fonds Q (Casablanca: Maṭbacat al-Najāḥ al-Jadīda, 2001-2002), 172-173, No. 171. 
"written and illuminated by [...] (kataba-hu wa-dhahhaba-hu ...)".12 Similarly, a miniature Maghribī Qurān in the Saxon State and University Library of Dresden was completed in $580 / 1184$ by a certain Muhammad b. 'Abd Allāh b. 'Alī al-Murrī (or al-Marī, i.e. from Almería), who "wrote, vocalized, and illuminated it (kataba-hu wa-dabața-hu wa-dhahhaba-hu)".13

If, as it seems, the copyist and the illuminator of the Munich Qurān were not the same person, it is anything but straightforward to determine which of the two did what exactly. The Andalusi biographical dictionaries claim that Quranic calligraphers were first and foremost religious scholars, trained in Quranic recitation (tajwìd) and variant readings ( $q i r \bar{a} \bar{a} t)$, and praised on account of their accuracy in vocalizing (dabț, tanqīt) the text of the Revelation. ${ }^{14}$ In the Andalusi-Maghribì tradition, however, the practice of Quranic vocalization also had considerable aesthetic connotations, given the rich polychromy that characterizes this system, which differs significantly from that of coeval manuscripts from the eastern Islamic world. The distinctive Andalusī way of vocalizing the Qurān, based on the practice of early Medinan scholars, seems to have developed in the recitation circles established by Mālik b. Anas (d. 179/795), and was later adopted in the lands where the Mālikì school of law became predominant, especially Muslim Iberia. ${ }^{15}$ In his treatise al-Muhkam fi naqț al-mașāhif ("The Precise on the Vocalisation of Qurāns"), the Denian scholar Abū 'Amr 'Uthmān al-Dānī (d. 444/1053) insists on the specificity of the dotting employed by the "vocalizers of our country (nuqqāt bilādi-nāa)". He refers to the authoritative model established by Ḥakīm b. 'Imrān al-Muqri', "the

12 On Ms. 18791 of the Tunis National Library see above, note 7. A second Qurān in the same library, Ms. $13727(16.5 \times 16 \mathrm{~cm})$, was copied and illuminated by Muhammad Ibn Ghațūus in 564/1168-1169: see Sharīfì, Khuṭūt al-mașāhif, 272-274; Dandel, "Ibn Ġațțūs", 18; Le Maroc medieval: un empire de l'Afrique à l'Espagne, catalogue of the Paris exhibition, 17.10.201419.01.2015 (Paris: Hazan \& Musée du Louvre, 2015), 354-355, nos. 208-209.

13 Ms. Ea. $293(10 \times 9.5 \mathrm{~cm})$, on which see Heinrich Leberecht Fleischer, Catalogus codicum manuscriptorum orientalium Bibliothecae Regiae Dresdensis (Leipzig: Vogel, 1831), 44.

14 Umberto Bongianino, "Quelques remarques sur l'origine des écritures coraniques arrondies en al-Andalus ( $\mathrm{v}^{\mathrm{e}} / \mathrm{XI}^{\mathrm{e}}-\mathrm{VI}$ e $/ \mathrm{XII}^{\mathrm{e}}$ siècles)", Al-Qanțara 38 (July 2017), 153-187: 163164 .

15 Alain George, "Coloured Dots and the Question of Regional Origins in Early Qur’ansPart I", Journal of Qur'anic Studies 17 (January 2015), 1-44: 7-11; Yasin Dutton, "Red Dots, Green Dots, Yellow Dots and Blue: Some Reflections on the Vocalisation of Early Qur'anic Manuscripts -Part I", Journal of Qur'anic Studies 1 (January 1999), 115-140: 117-120. 
vocalizer of the people of al-Andalus (näqit ahl al-Andalus)", in a codex written in 227/842, described in the Muhkam as follows:

The vowels were indicated by red dots, the hamazāt by yellow [dots], and initial alifāt al-wașl [i.e. the "connected" alif without glottal stop] by green [dots]. Silāt, sukūn, and tashdìd were marked with a thin red pen (bi-qalam daqiq bi-l-humra), in the way that we have related about the vocalizers of our land. The șila was above the alif if preceded by a fatha, below it if preceded by a kasra, and along its middle if preceded by a damma. Alifs omitted in the rasm (al-alifät al-mahdhüfät min al-rasm) were included in an abbreviated form (ikhtișār) in red. There was a small circle in red for unpronounced letters (hurüf zawāidd) and lightened letters (hurūf mukhaffafa), as in "an [ā]", "la’awda ü" [Q. 9:47], "a-fa'im mitta"

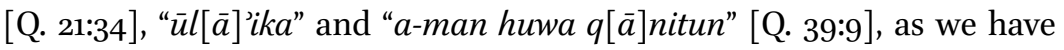
shown about the people of Medina, and as it has become the custom of the people of our land. ${ }^{16}$

In his work, al-Dānī refers to Quranic manuscripts vocalized through dots, but during the 11th century, Andalusī Qurāns saw the introduction of a new vocalization system featuring the symbols for damma, fatha, and kasra still in use today. In Andalusī Qurāns, however, these symbols continued to be penned in red ink. Moreover, the use of coloured dots was maintained in two cases: yellow (or orange) dots marking the hamza above or below alif, and green dots signalling alif al-wașl. This is precisely what we see in the Munich Qur'ân [fig. 3], and in virtually all the other Quranic manuscripts produced in al-Andalus and the Maghrib in the 12th century. As mentioned by al-Dānī, several other symbols continued to be traced "in a thin red pen": horizontal strokes for șila and madda, vertical ones for dagger alif, and small circles for zawāid and mukhaffafa letters.

In the Munich Qurān, a significant deviation from al-Dānī's description is that the symbols of sukün and tashdìd are traced in blue ink, and not in red. This practice, not mentioned in any of al-Dāni’s treatises, is first referred to in the work of the Sevillian scholar Ibn Wathīq (d. 654/1256) as an alternative to the use of red. ${ }^{17}$ From the surviving manuscripts, it is clear that this was by far the

16 Abū 'Amr 'Uthmān b. Sa'̄id Al-Dānī, al-Muḥkam fìnaqț al-maṣāhif, ed. 'Izzat Ḥasan, (Damascus: Dār al-Fikr, 196o), 87. This passage is translated and discussed in George, "Coloured Dots", 8-9. See also Dutton, "Red Dots", 119.

17 Muhammad al-Idrīsī al-Ṭāhirī, Isti'māl al-alwān fì ișțilāhāa dạt al-maṣāhị 'ind 'ulamā’al- 


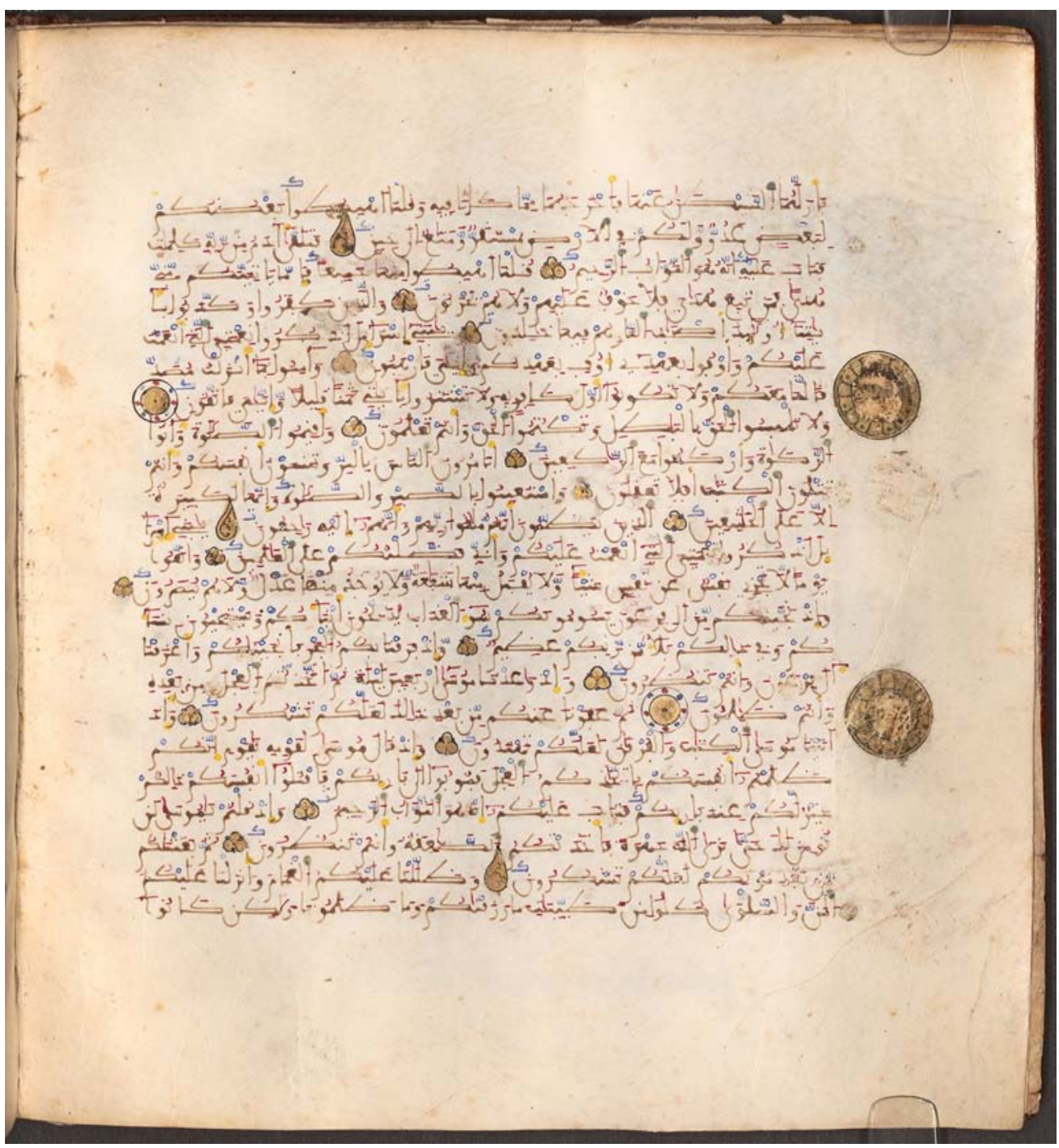

FIGURE 3 Munich, BSB, Cod. arab. 4, f. 5b. Full-text page (2:35-56)

(C) BAYERISCHE STAATSBIBLIOTHEK

preferred choice of Andalusī vocalizers since the end of the 11th century, as demonstrated by a codex dated $483 / 1090$ in the Uppsala University Library. ${ }^{18}$ These scholars, therefore, had to produce and employ four different coloured

Andalus wa-l-Maghrib: bayn al-ta’șīl al-fiqhī wa-l-tațbīq al-manhajī (Casablanca: Mațba'at al-Najāḥ al-Jadīda, 2009), 68.

18 Ms. O. Bj. $48(17 \times 14.5 \mathrm{~cm})$, for which see Carl J. Tornberg, Codices arabici, persici et turcici 
inks (red, blue, yellow, and green) in addition to the black ink they used for transcribing the consonantal text of the Quràn (rasm), which definitely blurs the line between a copyist's job and that of an illuminator. For this reason, Quranic scribes and vocalizers were also artists and perceived as such, and their work was appreciated for its accuracy and reliability as well as for its beauty. This is evident from medieval accounts such as that of Abū al-Ḥasan 'Alī b. al-Ṣayyād al-Fāsī, dated 726/1325-1326 and transmitted by the Mamluk historian al-Ṣafadī (696/1297-764/1363), which describes the work of Muhammad Ibn Ghațtūs in these terms:

I myself saw a Qurānn, or possibly more, penned by him [i.e. Muhammad Ibn Ghațtūs], and it was indeed a marvellous thing, for the beauty of its execution (husn al-wad ') and the exquisiteness of the strokes (ricayyat almarsüm). Each vowel was marked very neatly with one colour: the shadda and the jazm [i.e. the sukūn] with blue (läzaward); damma, kasra, and fatha with the colour of [red] lac (lakk); green (al-akhdar) was used for hamza with kasra, and yellow (al-asfar) for hamza with fatha. Everything was executed without blemishes, and there was not a single $w \bar{a} w$, or alif, or any other letter or word in the margin ( fi al-häshiya) or outside [the text block]. It was as if every imperfection had been removed. ${ }^{19}$

This description could very well be applied to the Munich Qurān, although produced some thirty years before Muhammad Ibn Ghațtūs began his career in the 116os. In this codex, moreover, the anonymous calligrapher went as far as to mark every single recitation pause (waqf) with superscript letters traced in the same blue ink used for sukūn and tashdīd: a miniature tä indicates the "perfect pause" (al-waqf al-tāmm), a miniature kāf signals the "sufficient pause" (al-waqf $a l-k \bar{a} f \bar{\imath}$ ), and a miniature $h \bar{a}^{3}$ marks the "good pause" (al-waqf al-hasan). This unique feature is explained in detail in a prefatory note written in gold ink and enclosed in two illuminated frames on folios 1b-2a [fig. 4], which reads:

Bibliothecae Regiae Universitatis Upsaliensis, (Lund: Berling, 1849), 245-246, no. CCCLXXI; Le Maroc médiéval, 224, no. 127.

19 Șalāḥ al-Dīn Khalīl b. Aybak al-Ṣafadī, Al-Wãfí bi-l-wafayāt, ed. Aḥmad al-Arnāūṭ and Muḥammad Turkī Farhān (Beirut: Dār Iḥyāe al-Turāth al-'Arabī, 200o), III, 28o-281, no. 1433. Note that al-Ṣafadì misunderstands the function of green and yellow dots: instead of hamza with kasra and hamza with fatha, they mark hamzat al-qaț and hamzat al-wașl. For a Spanish translation and discussion of this passage, see José Miguel Puerta Vílchez, La aventura del cálamo: historia, formas y artistas de la caligrafía árabe (Granada: Edilux, 2007), 165-167. 


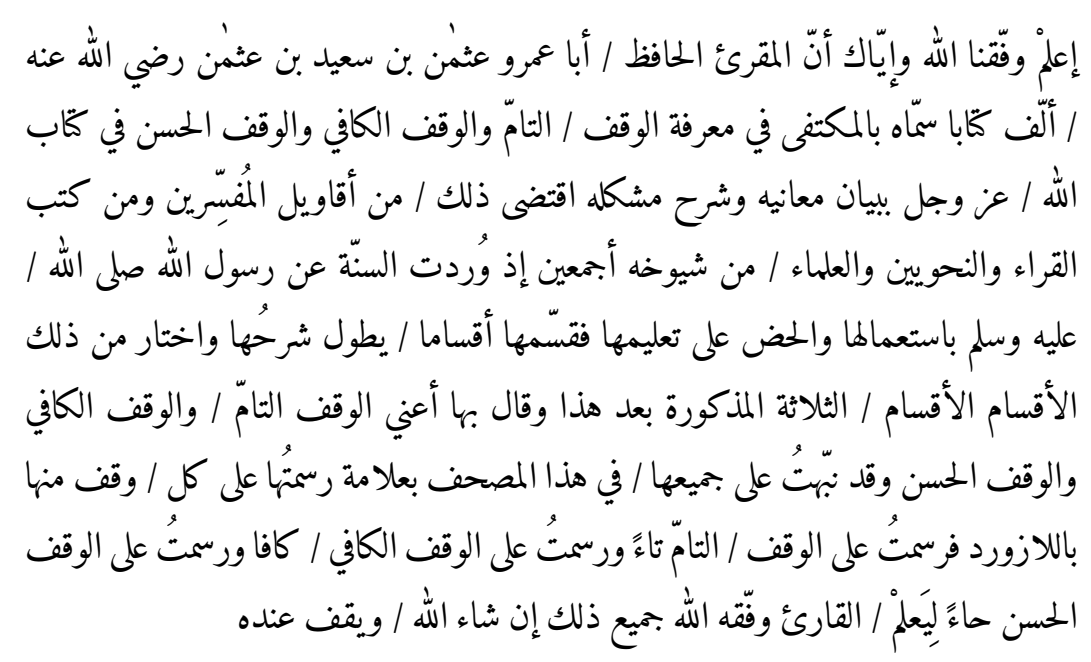

God help us! Know and be aware that the master reciter Abū 'Amr 'Uthmān b. Sa'īd b. 'Uthmān [al-Dānī] wrote a treatise which he entitled The Adequate [manual] for the knowledge of the perfect pause, the sufficient pause, and the good pause in [the recitation of] the Book of God almighty, with an explanation of its meanings and elucidation of its difficulties. He did so by drawing upon the opinions of the exegetes and the works of the reciters, grammarians, and religious scholars from among his masters, since the Prophet-peace be upon him-established the use [of these pauses] and encouraged their study. [Al-Dānī] divided them into categories, the explanation of which would be too long and, from these categories, he selected the three that we shall mention, namely the perfect pause, the sufficient pause, and the good pause. I have marked all of them in this manuscript, using symbols that I have traced in blue above each pause: a $t \bar{a}$ 'above the perfect pause, a $k \bar{a} f$ above the sufficient pause, and a $h \vec{a}$ ' above the good pause. Let the reciter be aware of all this, and may God help him, and may he stick to it, God willing.

This extraordinary document attests to the degree of competence and perfectionism achieved by our anonymous scribe, and possibly by other 12th-century Quranic calligraphers whose work has unfortunately not survived. Moreover, it confirms the enduring currency of the treatises on Quranic recitation and variant readings authored by al-Dānī in the previous century, as well as his unchallenged reputation as the foremost Andalusī authority on these matters. $^{20}$ Indeed, there is copious evidence that his work on recitation pauses 


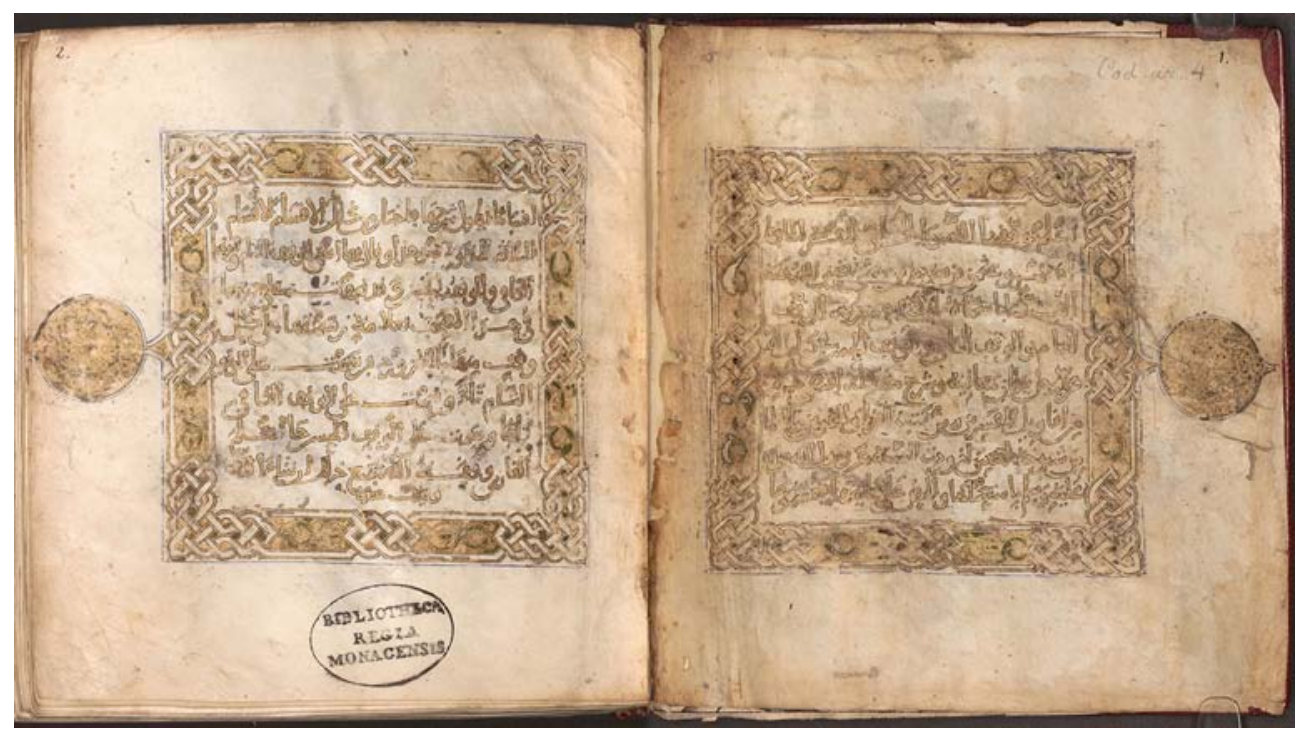

FIgURE 4 Munich, BSB, Cod. arab. 4, ff. 1b-2a. Prefatory note in Maghribī thuluth, enclosed in two illuminated frames with marginal vignettes

(C) BAYERISCHE STAATSBIBLIOTHEK

continued to be transcribed and taught in al-Andalus until the fall of Granada, while Aljamiado translations of other treatises by the same author circulated within the Morisco communities of 16 th-century Spain. ${ }^{21}$ Just like al-Dānī, whoever commissioned the Munich Qur'ān was also interested in the different traditions discussing the number of verses, words and letters contained in the Revelation, as suggested by another note written in gold ink and enclosed in a similar illuminated frame, after the finispieces (f. 129b):

$$
\begin{aligned}
& \text { عدد آي القرآن في المدني ستة ألاف آية ومائتا آية / وسبع عشرة آية بفاتحة الكتاب وهو المدني }
\end{aligned}
$$

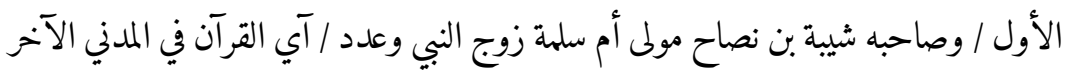

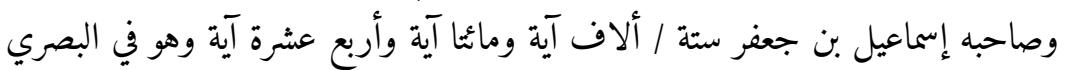

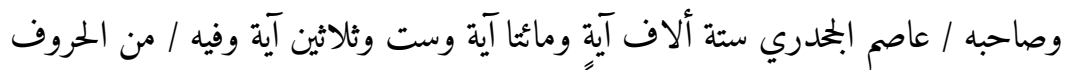

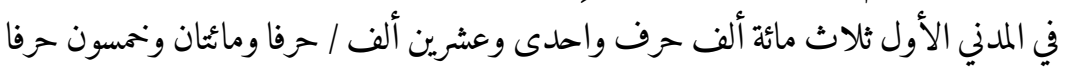

"Al-Dānī, Abū 'Amr", in Biblioteca de Al Andalus, ed. Jorge Lirola Delgado and José Miguel Puerta Vílchez (Almería: Fundación Ibn Tufayl de Estudios Árabes, 2004-2012), I, 308-322. 21 Juan Pablo Arias Torres, "Un fragmento del Kitāb al-Muktafà de al-Dānī entre los libros árabes de Cútar (Málaga)", Anaquel de Estudios Árabes 26 (2015), 19-28: 23. 


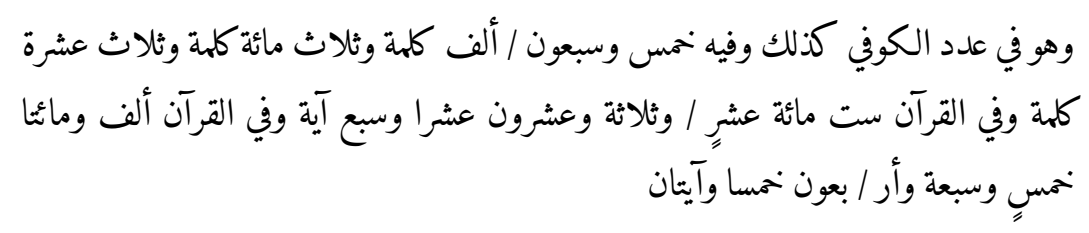

The number of verses in the Qur'ān according to the Medinan [tradition] is 6217 including the Fätiha. This is the first Medinan [tradition], attributed to Shayba b. Nașsāh, client to Umm Salama, the wife of the Prophet. The number of verses in the Qurān according to the second Medinan [tradition], attributed to Ismāîl b. Ja'far, is 6 214, while in the Basran tradition established by 'Āṣim al-Jahdarī [the number of verses] is 6 236. According to the first Medinan [tradition], the number of letters in the Qur'ān is $3^{2125}$, and likewise according to the Kufan [tradition]. [The Qur'ān] is comprised of 75313 words. In the Qur'ān, there are 623 groups of ten verses, remainder 7 , and 1247 groups of five verses, remainder 2.

The striking way in which scholarship and calligraphy are combined in these explanatory notes reflects the professionalism of the manuscript's maker(s), but also the interests and mentality of its patron and first owner. He must have been a competent scholar of the Qurān, who instructed Zakariyā the illuminator to include these highly technical texts at the beginning and end of the book, and asked the anonymous scribe to note the additional recitation marks. Even if not mentioned explicitly, these counts are drawn from another treatise by al-Dānī, titled al-Bayān fí 'add āy al-Qur'ān ("Elucidation of the Number of Verses in the Qur'ān"). ${ }^{22}$ It would indeed be difficult to imagine a better example of the interconnection between scriptural erudition, recitational practices, and aesthetic thinking which characterized the medieval Islamic West.

The winding calligraphic style of both these notes, the Fätiha [fig. 2], and the central parts of the double colophon [fig. 1] differs noticeably from the angular Kufic script used in the süra headings and the outer frames of the colophon and the Fätiha. Even though $f \bar{a}$ ' and $q \bar{a} f$ are dotted according to the Maghribī system (one dot below the $f \bar{a}$ ' and one above $q \bar{a} f$ ), this script clearly

22 Abū 'Amr 'Uthmān b. Sa'īd al-Dānī, al-Bayān fì 'add āy al-Qur'ān, ed. Ghānim Qaddūrī alḤamad, (Kuwait: Markaz al-Makhțūtāt wa-l-Turāth wa-l-Wathāiq, 1994), 73-83. I wish to thank Juan Pablo Arias Torres for this and other precious suggestions. 
imitates the calligraphy of the Islamic East, with its distinctive letter shapes, ligatures, and ductus. For this reason, it is generally referred to as Mashriqi script or Maghribi thuluth, after the name of one of the most famous eastern styles, thulth or thuluth, "the principal chancery script with pronounced curvilinear features". ${ }^{23}$ Another definition of Maghribì thuluth developed by modern Moroccan scholarship is that of Mashriqi mutamaghrab ("Maghribized Mashriqi"), which emphasizes the creative reinterpretation of eastern models carried out by most Maghribī calligraphers. ${ }^{24}$ The Munich Qur'ān represents the earliest dated evidence for the use of this calligraphic style in an Andalusī manuscript, standing at the beginning of a long tradition that would become fully established in the second half of the 12th century. At least twelve Qurāns produced between 534/1139 and 6oo/1204 (including those copied by 'Abd Allāh and Muhammad Ibn Ghațtūs) feature colophons, dedications, and didactic notes written in Maghribī thuluth. ${ }^{25}$ This was apparently intended as a 'display script' and a calligrapher's show of bravura, as demonstrated by the fact that it is always artistically executed either in chrysography outlined in black ink, or in reserve over a blue or leaf-gold background.

With the exception of the Fätiha, the suras of the Munich Qurān were copied in the miniature Maghribī style common to all the 12th-century Quranic codices in small square format that survive from the Islamic West. This script is characterized by thin threadlike strokes produced by a small qalam with a sharp nib, possibly made of metal. Once labelled 'Andalusî' to distinguish it from other types of Maghribī scripts, this peculiar style was equally employed by Quranic copyists on both sides of the Strait of Gibraltar, hence the wise

23 See "Thuluth script" in Adam Gacek, Arabic Manuscripts: A Vademecum for Readers (Leiden/Boston: Brill, 2012), 274-275. For Maghribì thuluth and the use of Mashriqī scripts in the Maghrib, see Muhammad al-Manūnī, Ta’rīkh al-wirāqa al-Maghribiyya. Șinā́at almakhțūt al-Maghribī min al-'așr al-wasịt ilā al-fatra al-mu'ạșira (Rabat: Jāmi'at Muhammad al-Khāmis, 1991), 47; 'Umar Afā, and Muhammad al-Maghrāwī, Al-Khaț̣ al-Maghribī: ta'rīkh wa-wāqi' wa-āfāq (Rabat: Wizārat al-Awqāf, 2013), 63-64.

24 Al-Manūnī, Ta’’īkh al-wirāqa, 14; Afā \& al-Maghrāwī Al-Khațt al-Maghribī, 63-64.

25 Three interesting examples are: Ms. RES $/ 272$ of the Madrid National Library $(8 \times 7 \mathrm{~cm})$, a miniature Qurān copied in Almería in 534/1139, with a colophon in Maghribī thuluth chrysography, on which see Bongianino, "Quelques remarques", 176-178; the abovementioned Ms. R. 33 of the Topkapı Palace Library, with a Maghribi thuluth dedication to the Almohad prince Abū Ya'qūb executed in reserve over a leaf-gold background (see above, note 9); and Ms. 934 of the Rabat National Library $(24.6 \times 22.5 \mathrm{~cm})$, a Qurān copied in 598/1202, with a note included in the two finispieces (ff. 145 b-146a), which gives the number of verses, letters, words, dots, groups of ten verses, groups of five verses, prostrations, and chapters in the Qurān, written in Maghribì thuluth in reserve over a blue background (see Sharīfî, Khuțūt al-mașāhif, 281-285). 
decision to abandon this misleading geographical designation. ${ }^{26}$ Despite the opinion of some scholars, the fact that $f \bar{a}^{\prime}, q \bar{a} f$ and $n \bar{u} n$ in final position always bear a diacritical dot is not exclusively associated with this style. ${ }^{27}$ What sets this miniature script aside from all the other Maghribì hands is its angular aspect, obtained through the complete suppression of the oval bodies of $s \bar{a} d$, $d \bar{a} d, t \bar{a}$, and $z \bar{a}^{3}$, and of the rounded variant of initial and medial $k \bar{a} f$, with its semi-circular stem. These elements are all replaced by parallel horizontal lines, often extremely elongated, joined together by short strokes, either vertical or oblique. The frequent elongation of letters (and of ligatures between letters) in the Munich Qur'ān harks back to the ancient Abbasid scripts used in early Qurāns, and must have also functioned as a visual encouragement to pronounce each word carefully, thus adding solemnity to the recitation [fig. 5]. ${ }^{28}$ The calligrapher's aim was arguably to give the script an archaizing aspect by evoking the angularity of Kufic, but also to impress the readers with his skills and mastery of even the most minute strokes. It should be noted that similar scripts are sometimes also found in non-Quranic manuscripts produced in the same period and region, mostly combined with illumination, as a means of visually conveying the prestige and authoritativeness of a particular recension of a work. ${ }^{29}$

The only attempt at a palaeographic analysis of this calligraphic style, made by the Algerian scholar Muhammad Sharifî in 1982, was based on the script employed by 'Abd Allāh Ibn Ghațūus in a Qur'ān dated 557/1161-1162, but can perfectly be applied to the Munich Qur'ān, too [fig. 6]. ${ }^{30}$ In addition to the frequent elongation of certain letters and ligatures, Sharifi remarks on the use of a double baseline in some words, through the rightward elongation of the body of medial and final jim, $h \bar{a}^{3}$, and $k h \bar{a}$, in the shape of a line stretching below

26 See "Andalusī script" in Gacek, Arabic Manuscripts, 8-9; Tim Stanley, The Qur'an and Calligraphy. A Selection of Fine Manuscript Material (London: Bernard Quaritch, 1996), 21-22.

27 See, for instance, Muḥammad al-Manūnī, "Ta’rīkh al-Mușhaf al-Sharīf bi-l-Maghrib", Majallat Ma'had al-Makhțūtāt al-'Arabiyya 1 (May 1969), 3-47: 16; David James, The Master Scribes. Qur'ans of the 1oth to 14th Centuries, The Nasser D. Khalili Collection of Islamic Art, II (London: The Nour Foundation in association with Azimuth Editions and Oxford University Press, 1992), 89-91.

28 See "Early Abbasid scripts" in Gacek, Arabic Manuscripts, 97-98.

29 See, for instance, a copy of the exegetical work al-Hidāya ilā bulūgh al-nihāya by Makkī b. Abī Taalib al-Qaysī al-Qurțubī, dated 485/1092 (Rabat National Library, Ms. 337 ك); a copy of al-Zubaydì's dictionary Mukhtasar al-'Ayn, dated 518/1124 (Fes, Qarawiyyīn Library, Ms. 1238); and a copy of the Șahịh Muslim dated 573/1178 (Rabat National Library, Ms. 586 ج).

30 Cairo National Library, Ms. 196 مصحف $(18.5 \times 17.5 \mathrm{~cm})$, on which see Sharifî, Khuțūt almașāhif, 259-265. 


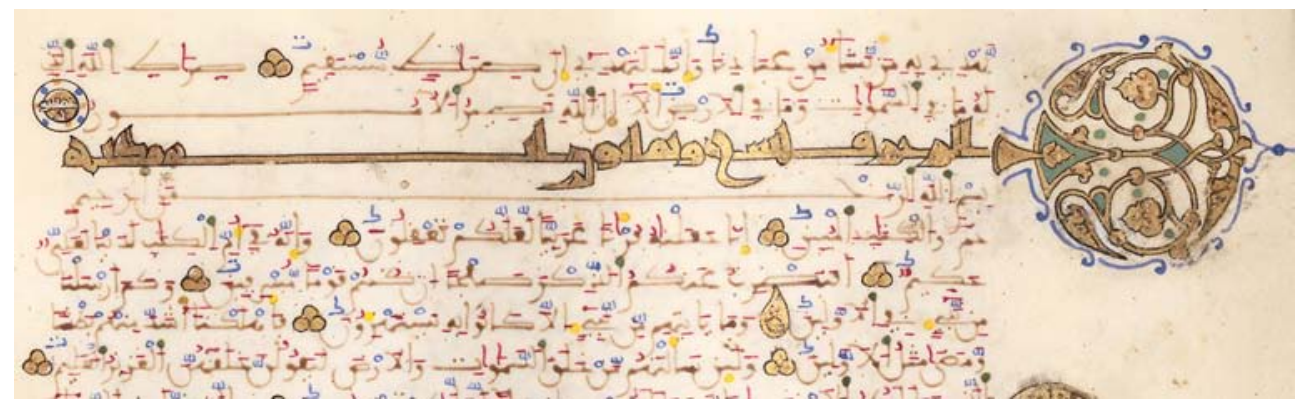

FIGURE 5 Munich, BSB, Cod. arab. 4, f. 10ob, detail. End of Sūrat al-Shūrā (42:52-53) and beginning of Sūrat al-Zukhruf (43:1-8). Illuminated heading of Sūrat al-Zukhruf, with marginal vignette and title in gold Kufic script. Note the elongations of certain letters and ligatures on ll. 1-2, and of the basmala on l. 4.

(C) BAYERISCHE STAATSBIBLIOTHEK

the preceding letters. ${ }^{31}$ The same effect is sometimes achieved through the horizontal extension of the tail of final $y \bar{a}$ ' räjii $a$ ( " $y \bar{a}^{\prime}$ turned backwards").

Other calligraphic traits observable in the script of the Munich Quràn, common to most contemporary Quranic manuscripts from al-Andalus and the Maghrib, are:

- The leftward inclination of the head serifs of alif, lām, and final kāf;

- Final $b \vec{a}^{\prime}, t \vec{a}^{\prime}, t h \vec{a}^{3}$, and $f \vec{a}$ terminate with a long horizontal stroke without the upward denticle at the end;

- Long, oblique stems of $t \bar{a}^{3}$, and $z \bar{a}^{3}$;

- Ample initial 'ayn traced with an oversized curl;

- Final mim always has a long, plunging tail curled leftwards;

- Isolated läm-alif is always drawn as two separate strokes, both curved, intersecting near the baseline;

- The baseline ligatures between the letters $b \bar{a}^{3}, t \bar{a}^{\prime}, t h \bar{a}^{3}, \sin$, shìn, 'ayn, ghayn, $f \bar{a}, q \bar{a} f, l \bar{a} m, n \bar{u} n$ and $y \bar{a}^{\prime}$ present an accentuated saw-toothed profile. The same can be said about the lower part of medial 'ayn, ghayn, făa', and $q \bar{a} f$, often rendered as an open space in the shape of a triangle.

The resemblance between the script of the Munich Quraan, that of 'Abd Allāh Ibn Ghatțūs 23 years later, and that of other 12th-century Andalusī calligraphers whose work has survived is indeed remarkable. This suggests that a well-codified and widely accepted mode of Quranic calligraphy-or rather, micrography — was among the hallmarks of Maghribì visual culture and religious praxis. But the characteristic script, format, and system of vocalization of

31 Sharīî̀, Khuțūṭal-mașāhifi, 277. 


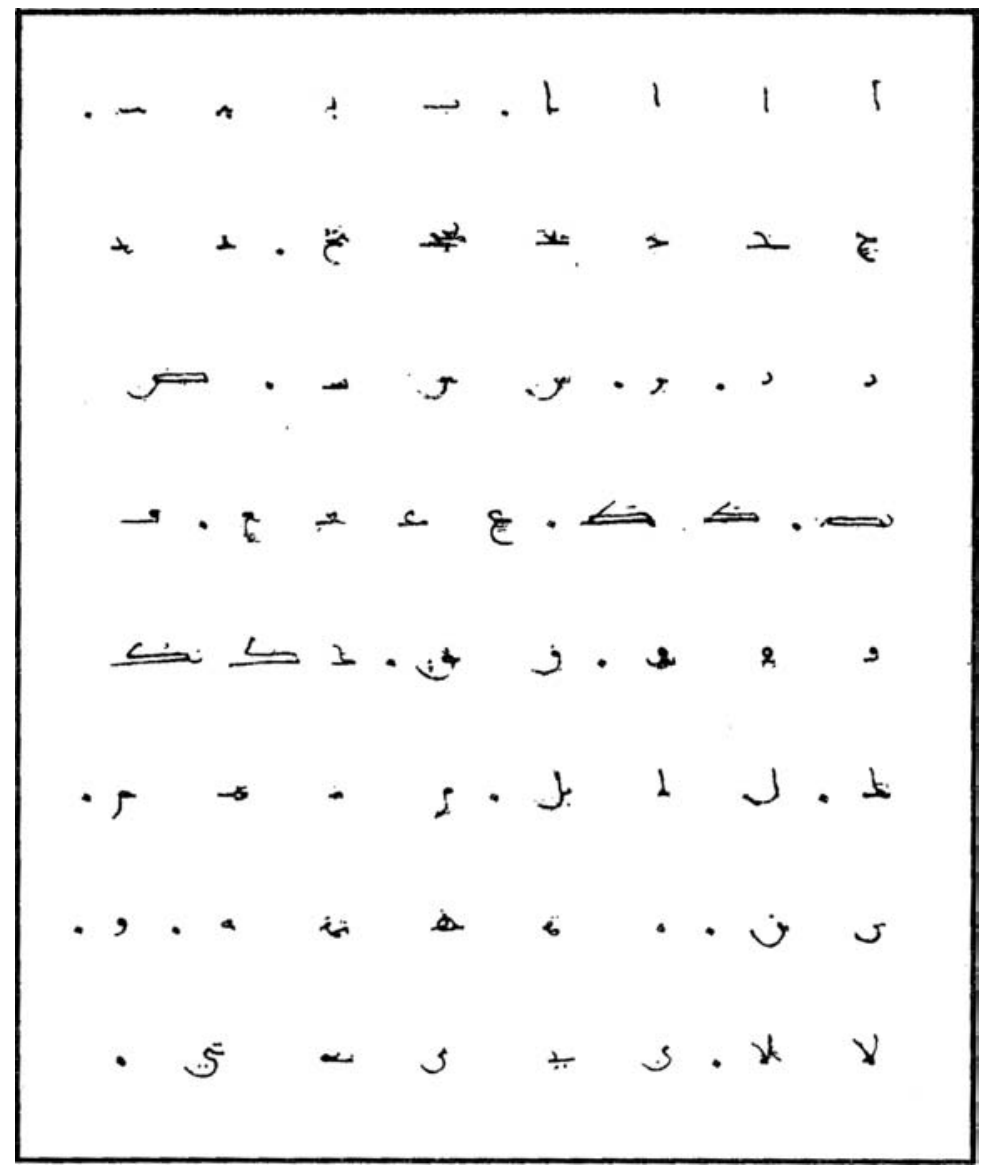

FIGURE 6 Muhammad Shariffi's palaeographic table for the script used by 'Abd Allāh b. Ghaț̣̂̄

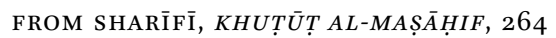

these Qurāns find parallels in a number of equally distinctive textual features, first and foremost the adherence to the Medinan reading (qiräa) of Warsh from Nāfì , which is also the one followed in the Munich Qur'ān.

\section{5}

\section{Sūra Titles and Textual Divisions}

A second interesting feature shared by Maghribī Quranic manuscripts is the preference for certain sūra titles different from those used in the contemporary Islamic East. For instance, in the Munich Qurān the title of süra 26 is al-Zulla ("the Shadow"), and not al-Shu'arä' ("the Poets") as in the eastern tra- 
dition; süra 98 is called al-Bariyya ("the Creatures"), and not al-Bayyina ("the Clear Evidence"); sūra 104 is titled al-Huțama ("the Crusher"), not al-Humaza ("the Slanderer"), and so forth. As already remarked by Juan Pablo Arias Torres and François Déroche, these apparently trivial variations could help us date and identify regional trends or the work of specific scribes just as much as paleographic and codicological analyses, and are therefore very important to record and compare. ${ }^{32}$ Some of these specifically Maghribī titles are mentioned and employed by al-Dānī in his treatises, but others seem to be found exclusively in Quranic manuscripts. Also, the number of verses in each süra (which is always indicated in süra headings) presents conspicuous idiosyncrasies. The copyist of the Munich Qurān followed what al-Dānī calls "the first Medinan count" in his Bayān, a system transmitted by the early Medinan scholar Nāfic that departs noticeably from other eastern counts, such as the Basran or the Kufan. ${ }^{33}$ What follows is a complete list of süra titles and verse counts as given in the Munich Qur'ān; all differences from the 1924 Cairo edition - which follows the reading of Ḥafṣ from 'Āsim and the Kufan verse count-are highlighted in bold:

$\begin{array}{ll}\text { 1. } & \text { Fātihat al-Kitāb }(7) \\ \text { 2. } & \text { Al-Baqara }(\mathbf{2 8 5}) \\ \text { 3. } & \text { Al Imrān }(\mathbf{2 0 0}) \\ \text { 4. } & \text { Al-Nisā' }(\mathbf{1 7 5}) \\ \text { 5. } & \text { Al-Māida }(\mathbf{1 2 2}) \\ \text { 6. } & \text { - missing - (167) } \\ \text { 7. } & \text { Al-A'rāa }(\mathbf{2 0 6}) \\ \text { 8. } & \text { Al-Anfāl (76) } \\ \text { 9. } & \text { Al-Tawba (130) } \\ \text { 10. } & \text { Yūnus (109) } \\ \text { 11. } & \text { Hūd (122) } \\ \text { 12. } & \text { Yūsuf (111) }\end{array}$

13. Al-Ra'd (44)

14. Ibrāhìm (54)

15. Al-Hijr (99)

16. Al-Nahl (128)

17. Al-Isrā' (110)

18. Al-Kahf (105)

19. Maryam (99)

20. $T \bar{a}{ }^{\prime} H \bar{a}^{\prime}(\mathbf{1 3 4})$

21. Al-Anbiy $\bar{a}^{\prime}(\mathbf{1 1 1})$

22. Al-Hajj (76)

23. Al-Mu'minūn (119)

24. $A l-N \bar{u} r(62)$

32 Juan Pablo Arias Torres and François Déroche, "Reflexiones sobre la catalogación de ejemplares alcoránicos (a propósito del ms. 1397 de El Escorial)", Al-Qanțara 32 (January 2011), 243-26o: 248-25o. For a discussion of sūra titles in the Islamic tradition and a useful list of variants based on medieval sources see Lamya Kandil, "Die Surennamen in der offiziellen Kairiner Koranausgabe und ihre Varianten”, Der Islam 69 (1992), 44-6o. In this connection, see also Arent Jan Wensinck, Concordance et Indices de la Tradition Musulmane. Tome viII. Indices par Wim Raven et Jan Just Witkam (Leiden: Brill, 1988), 369-421.

33 Al-Dānī, Al-Bayān, $139 \mathrm{ff}$. It should be noted that in sūra 58, 62, 90, 91, 101, and 110, the verse count stated in the headings does not match the actual number of verses in the text: these are probably scribal mistakes. 


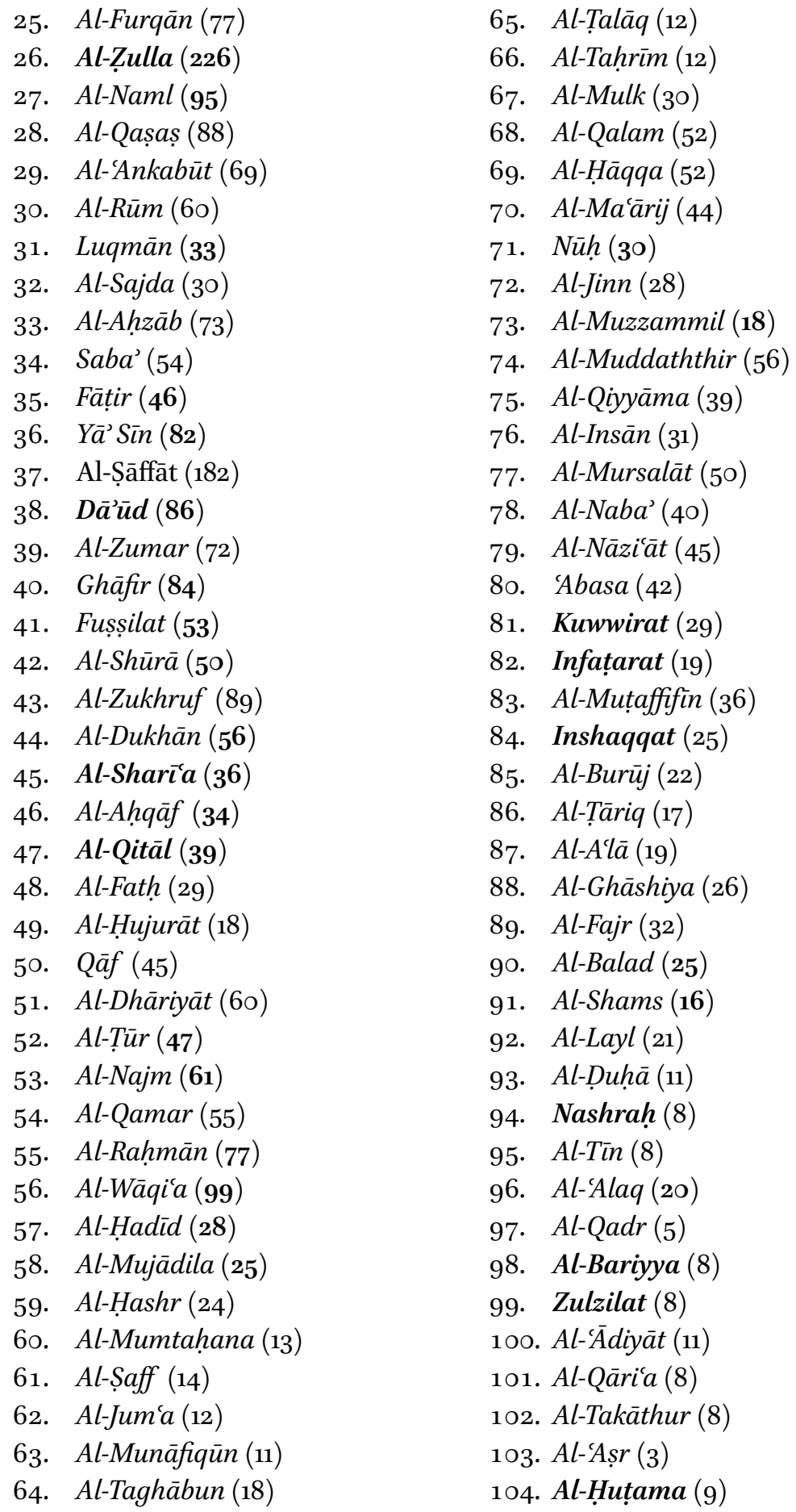


105. Al-Fül (5)

106. Quraysh (5)

107. Al-Din (6)

108. Al-Kawthar (3)

109. Al-Käfirün (6)
110. Al-Fath (4)

111. Al-Masad (5)

112. Al-Ṣamad (4)

113. Al-Falaq (5)

114. Al-Nās (6)

If similar lists could be drawn for all the dated Maghribī Quràns known to us, they would provide an invaluable benchmark for attributing undated manuscripts to specific contexts and periods with more confidence. However, most of these Qurāns are kept in Middle Eastern and North African libraries that only grant very limited access to their collections, and the single survey published to date covers a limited sample that only includes one manuscript from the 12 th century. ${ }^{34}$

A third and final idiosyncrasy of Maghribī Qur'āns is found in their complex system of textual division. In the Munich Qur'ann, the standard verse separator is represented by a cluster of three gilded roundels arranged into a triangle. However, every fifth verse is marked with a gilded Kufic $h \bar{a}$ (representing the digit 5 in the Arabic alphanumeric system or abjad), and every tenth verse ends with a gilded roundel surrounded by eight alternating blue and red dots. Each tenth-verse marker in the text block is always accompanied by a corresponding gilded medallion in the margin, consisting of a petalled circle enclosing a roundel in which the verse number is spelled out in Kufic chrysography ('ashara for the tenth verse, 'ishrün for the twentieth, and so forth). The text of the Qur'ān is then divided into sixty equal parts ( $a h z \bar{a} b$, sing. hizz), which are signalled by larger illuminated medallions in the margins, enclosing a roundel with the word hizb in Kufic chrysography. While these are all rather standard features, the Munich Qurān is further divided into ten equal parts, as well as ninths, eighths, sevenths, sixths, fifths, fourths, thirds, and halves, all of which are accurately indicated in the margins in bold Kufic chrysography, dotted and vocalized in blue [fig. 7]. Once again, it seems that the scribe placed all these division marks in accordance with the instructions provided by al-Dānī in his Bayān, with only very rare and minor departures.

In addition, the text is further divided into 27 equal sections called tajziāt Ramadān, rather than into the canonical thirty $a j z \bar{a}^{\prime}$ (sing. juz'). These sections refer to the first 27 nights of the holy month of Ramaḍan, and allow to recite the entire Qurān during tarāwih h, or night prayer, ending on the 27th night of the month, known as Laylat al-Qadr (the "Night of the Decree"), when the prophet Muhammad received his first revelation. The end of each tajzia is indicated by 


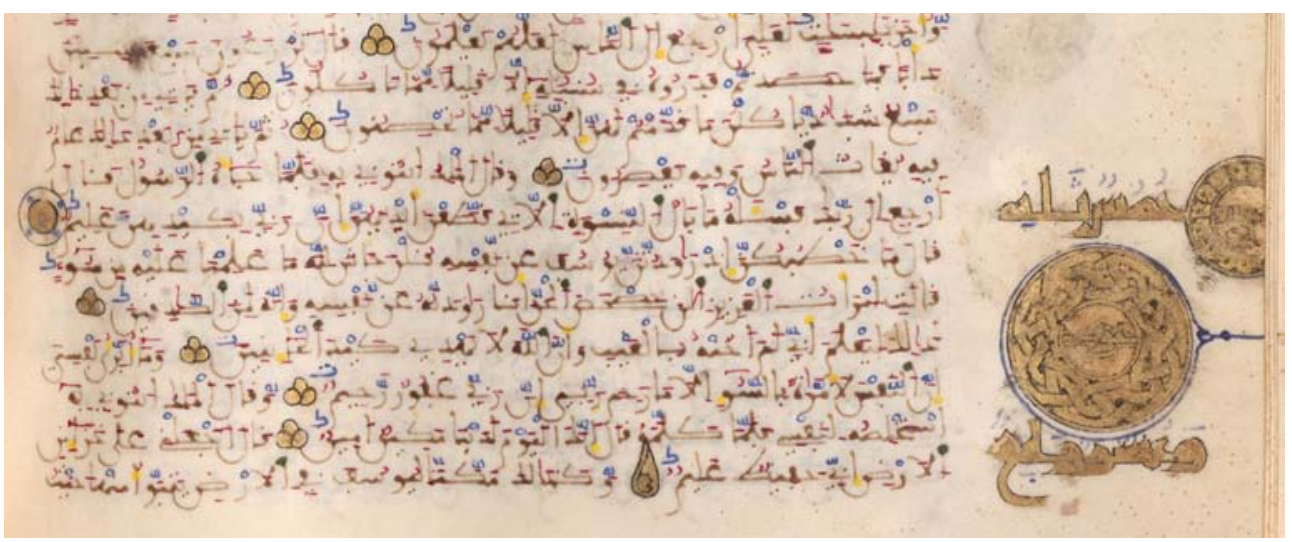

FIGURE 7 Munich, BSB, Cod. arab. 4, f. 48b, detail. Part of Sürat Yūsuf (12:47-56). In the margin is a hizb medallion (25th hizb, 12:53), a smaller medallion marking the 5oth verse of the süra, and two notes marking the completion of the second fifth and fourth tenth of the Qurann.

(C) BAYERISCHE STAATSBIBLIOTHEK

illuminated trilobed devices in the margins, containing the last word of the relevant passage in Kufic chrysography over a green background [fig. 8]. This kind of textual division, unparalleled in the Islamic East, seems to be specific to a group of Qurānic manuscripts produced in al-Andalus and Northwest Africa that await further study. ${ }^{35}$ The Munich Qurān represents one of the earliest surviving witnesses of this practice, which lasted until the early 17 th century among the Moriscos living in Habsburg Spain. ${ }^{36}$

\section{$6 \quad$ Conclusions}

Based on these elements, it is possible to draw some conclusions regarding the nature and purpose of this and other similar Quraanic manuscripts from the same period. As we have seen, the patron and/or copyist of the Munich Qurān must have been a religious scholar competent in Qurānic sciences, but also

35 See Carlo Alberto Anzuini, Imanoscritti coranici della Biblioteca Apostolica Vaticana e delle biblioteche romane (Vatican City: Biblioteca Apostolica Vaticana, 2001), 412; Teresa Espejo Arias, Juan Pablo Arias Torres, El corán de Cútar, Málaga: estudio introductorio (Seville: Junta de Andalucía, 2009), 84-85.

36 The use of tajziāt Ramadān is documented, for instance, in the aljamiado translation of the Qurān preserved in Ms. T235 of the Castilla-La Mancha Library in Toledo, completed in 1606. For a critical edition of this manuscript, see Consuelo López-Morillas, El Corán de Toledo. Edición y estudio del manuscrito 235 de la Biblioteca de Castilla La Mancha (Gijón: Ediciones Trea, 2011). 

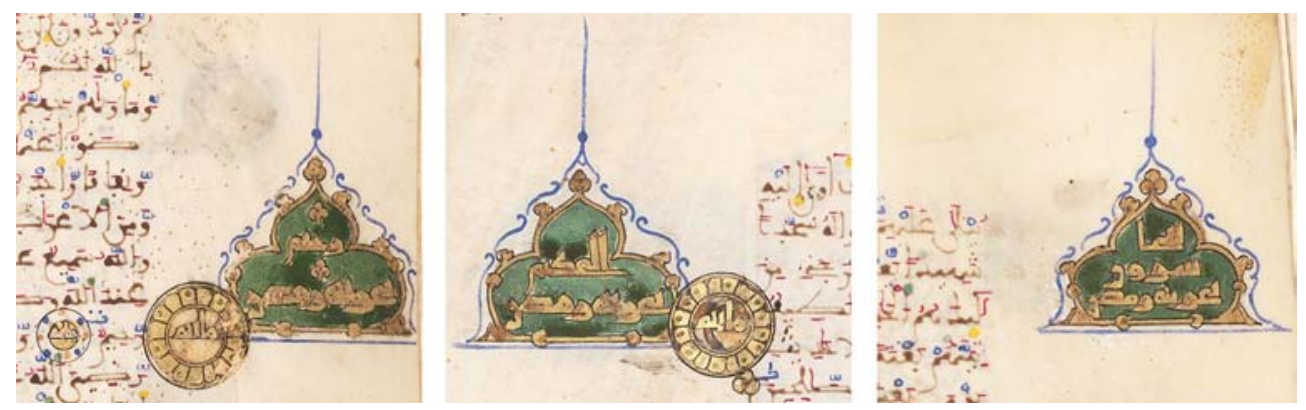

FIGURE 8 Munich, BSB, Cod. arab. 4, details of ff. 4ob, 5oa, 82b. Examples of tajziāt Ramadān in the margins

(C) BAYERISCHE STAATSBIBLIOTHEK

a man deeply concerned with producing an exemplar of the highest possible accuracy and visual appeal. The use of the atypical expression tahammama bi-iqāmat hādha al-mușhaf ("he took care of the realization of this Qur'ān") in the colophon emphasizes the patron's commitment to the task, confirmed by his choice to employ a professional illuminator-Zakariyā b. Muhammad b. Zakariyā al-Qurashī - to provide the manuscript with lavish frontispieces and finispieces. The Munich Qurān was not commissioned to be endowed to a mosque or religious institution, but for the owner's private use ("i-nafsi-hi") and for his son after him, and was arguably meant to become a cherished family heirloom handed down from father to son. Codices such as this probably functioned as personal or travel copies, to be read from during acts of familial devotion, especially in the holy month of Ramaḍan, as suggested by the division into 27 tajziàt. However, they also had a strong pedagogic purpose, since the extra-textual notes and the profusion of vocalization and orthoepic notation were clearly intended to instruct the reader in the art of correct recitation and memorisation. The plethora of textual divisions would have allowed different types of learners to tackle the Quranic text at different paces: hizb by hizb, tenth by tenth, seventh by seventh, and so forth. While larger Qurāns in multiple volumes were endowed to Andalusī and Maghribī mosques by the ruling elites for public recitation, it was through small manuscripts such as this that students and scholars prayed and exercised their reading in a domestic environment.

The Munich Qurān was produced at a turbulent time when the fortunes of the Almoravid dynasty were declining, and yet the cities of al-Andalus witnessed in this period a renewed cultural effervescence brought about by the rise of new local families of governors, judges, and jurists. The effacement of the owner's name may point to a moment of regime change, possibly coin- 
ciding with the downfall of the Almoravids, the second ța $i f a$ period, and the Almohad conquest of Iberia (1147-1172). The obliteration of names of patrons, owners, or calligraphers from medieval Maghribī colophons is an extremely rare phenomenon, and cannot simply be explained in terms of changes of ownership. A new owner would have added their name at the beginning of the book or after its colophon, without any need to erase someone else's name and titles from it. The only other instance of effacement in a 12th-century Andalusī manuscript (that I am aware of) was carried out at the expenses of an Almohad prince in a luxury copy of the Sahịh Muslim produced for his library in $573 / 1178$, in Murcia. ${ }^{37}$ His name, titles, and lineage were entirely expunged from the colophon, without any attempt to replace them with those of a new owner, while the signature of the calligrapher and the indication of the date and place of production were left intact. It is therefore possible that the patron of the Munich Quraan was also a governor, appointed by the Almoravid emir, or at least an Almoravid supporter of some consequenceperhaps the imamm or preacher at a major mosque-whose memory had to be eradicated.

Even if just speculatively, it is tempting to attribute the Munich Qurān to the scholarly and artistic milieu of Córdoba, the Almoravid capital of al-Andalus, based on the striking similarities in format, layout, and script with a codex copied and illuminated in Córdoba five years later, in 538/1143-1144 [Fig. 9]. ${ }^{38}$ This, too, is a lavishly illuminated manuscript penned by an anonymous calligrapher, who added after the colophon two handsome finispieces emblazoned with the words: "Abū 'Abd Allāh Muḥammad b. 'Alī b. Muḥammad b. Yahyyā alGhāfiqī al-Shārrī was born in Murcia, in the month of Shawwāl of the year 537, may God make him happy and successful". The scion of the important Murcian family of the Banū Yahyyā al-Ghāfiqī, Abū 'Abd Allāh al-Shārrī became a renowned transmitter of works of hadīth and figh and a scholar of qirāāa.$^{39}$ This manuscript was evidently commissioned to celebrate his birth, probably by his proud father. Similarly to the Munich Qur'ann, this is a fascinating example of a personal codex imbued with a sense of familial self-assertion and domestic intimacy. Interestingly, its copying and illumination were not

37 Rabat National Library, Ms. 586 ج.

38 Istanbul University Library, Ms. A $6755(18.2 \times 17.8 \mathrm{~cm})$, on which see Fehmi E. Karatay, İstanbul Üniversitesi Kütüphanesi Arapça Yazmalar Kataloğu (İstanbul: İstanbul Üniversitesi, 1951), I, 5, no. 13; Al-Andalus, 304-305, no. 75.

39 For a biography of Abū 'Abd Allāh al-Shārrī see Muhammad b. 'Abd Allāh b. al-Abbār alQuḍāīì, Al-Takmila li-Kitāb al-ṣila, ed. 'Abd al-Salām al-Harrās (Beirut: Dār al-Fikr, 1995), II, 128 , no. 331. 


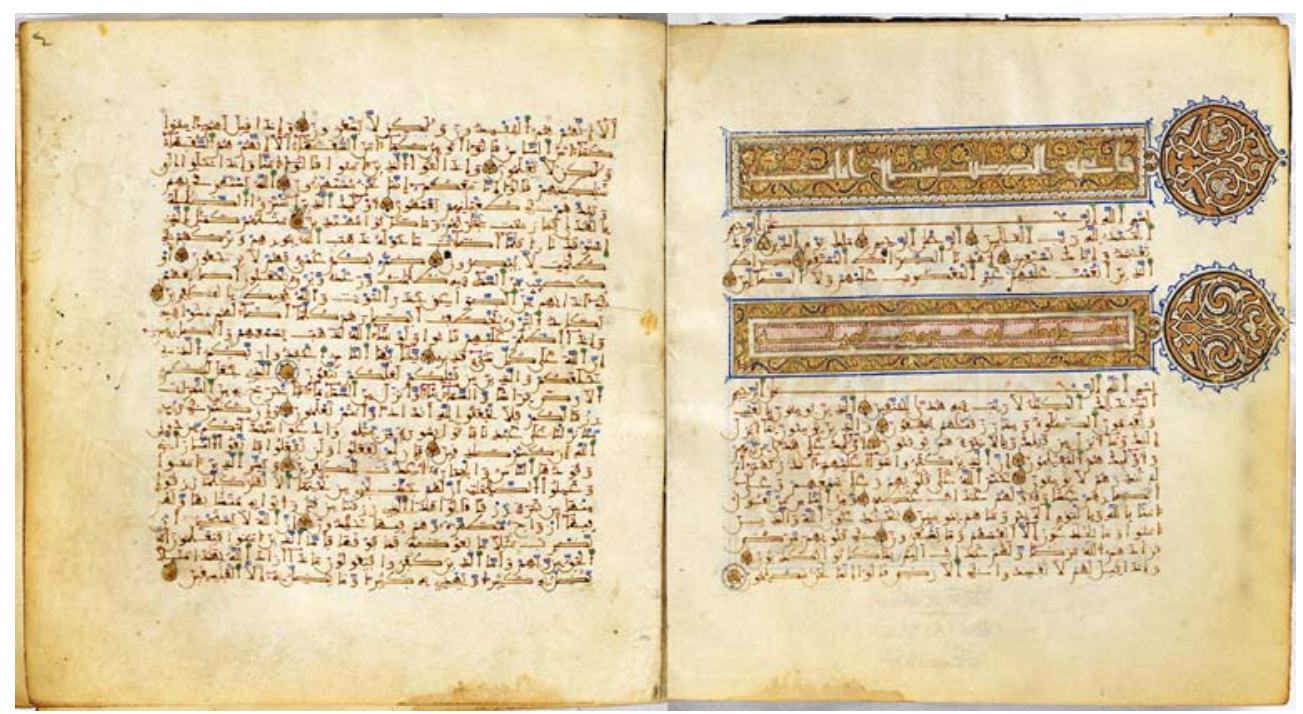

FIGURE 9 Istanbul University Library, Ms. A 6755, ff. 3b-4a, with the Fätiha and the beginning of Sūrat al-Baqara (1:1-2:25)

(C) ISTANBUL ÜNIVERSITESI KÜTÜPHANESI

entrusted to a Murcian master but to a Cordoban one, which might indicate the pre-eminence of this city in the arts of the Quraan during the last decades of Almoravid rule.

For its historical and art historical significance, the Munich Qurān can be considered one of the most remarkable artefacts to have survived from 12thcentury al-Andalus, and should be given pride of place within the increasingly growing corpus of the earliest Maghribì Qurāns known to us. Appended to this article is a list of dated Quranns in Maghribī script copied until the year 600/1203-1204, which updates the previous lists published by David James in 1992 and by François Déroche in 2001. ${ }^{40}$ A comparative study of these 27 manuscripts and their textual, codicological, and aesthetic features would be crucial to the advancement of scholarship on the arts of the book and the transmission of the Qurān in the medieval Islamic West, and should not be deferred any further. An important piece has been added to the jigsaw, but a lot more remains to be done as new material waits to be identified in libraries, museums, and private collections all over the world.

40 James, The Master Scribes, 89; François Déroche, "Cercles et entrelacs: format et décor des Corans maghrébins médiévaux”, Comptes rendus des séances de l'Académie des Inscriptions et Belles-Lettres 145 (January 2001), 593-620: 612. 


\section{Appendix: A List of Dated Qur'āns in Maghribī Script Arranged in Chronological Order ${ }^{41}$}

I. Rajab 398/10o8. Single folio from a codex in horizontal format $(14.8 \times$ $20.2 \mathrm{~cm}$ ). Istanbul, Turkish and Islamic Art Museum, Inv. ŞE 13216/1. ${ }^{42}$

II. Safar 432/1040. Single folio from a codex in horizontal format $(14.4 \times$ $17.5 \mathrm{~cm})$. Istanbul, Turkish and Islamic Art Museum, Inv. ŞE 13644/1. ${ }^{43}$

III. Ramaḍān 470/1078. Single-volume codex in miniature square format $(7.9 \times 7.9 \mathrm{~cm})$, copied in Córdoba for the wazìr 'Abd al-Malik b. Sirāj. Present location unknown. ${ }^{44}$

IV. Jumādā I 483/109o. Last volume from an eight-volume set in small rectangular format $(17 \times 14.5 \mathrm{~cm})$. Uppsala University Library, Ms. O.Bj. 48.45

V. 488/1094-1095. Single-volume codex in small square format $(15 \times$ $15 \mathrm{~cm}$ ), copied by 'Alī b. Muhammad al-Bațalyawsī. Medina, King 'Abd al-'Azīz Public Library, Ms. $19 .{ }^{46}$

VI. $\quad 533 / 1138-1139$. Single-volume codex in small square format $(17 \cdot 3 \times$ $16 \mathrm{~cm}$ ), illuminated and bound by Zakariyā b. Muhammad b. Zakariyā al-Qurashī. Munich, Bavarian State Library, Cod. arab. $4 .{ }^{47}$

41 Four manuscripts have been excluded from the list:

A) Topkapı Palace Library, Ms. R. 2, a paper codex in vertical format dated 509/1115 and $532 / 1137$, which was not written in Maghribī script despite what is stated in Karatay, Topkapı Sarayı Müzesi, I, 84-85, no. 302.

B) Topkapı Palace Library, Ms. R. 29, a paper codex in Maghribī script that, although mentioning the year 555/116o in its colophon, must date from the 1oth/16th century, based on its calligraphy and style of illumination (Karatay, Topkapı Sarayı Müzesi, I, 83, no. 297).

C) Istanbul University Library, Ms. A 6756, a miniature paper codex $(10.5 \times 10 \mathrm{~cm})$ with a colophon dated 500/1107, but which is in fact a 19th-century copy of an earlier manuscript (Karatay, İstanbul Üniversitesi Kütüphanesi, I, 4, no. 12).

D) Escorial Library, Ms. D. 1397, copied in Malaga by Mufaḍdal b. Muhammad b. Mufaḍdal in the year 701/1302, but repeatedly misdated to 500/1106-1107 (Déroche, "Cercles et entrelacs", 611) and to 601/1204 (Le Maroc médiéval, 36o, no. 213). A correct reading of its date has been provided in Arias \& Déroche, "Reflexiones". turcs et islamiques d'Istanbul", Revue des Études Islamiques 59 (1991), 229-236.

43 Déroche, "Deux fragments coraniques".

44 This manuscript was auctioned twice: Islamic and Indian Art, Bonham's, London, 6.4.20o6, lot 5; Art of the Islamic and Indian Worlds, Christie's King's Street, London, 7.10.2008, lot 97. The date allegedly given in the colophon remains to be ascertained.

45 See above, note 18.

46 I thank Professor 'Abd Allāh al-Muniff for having shared with me some images of this manuscript. The date seems plausible but it can no longer be verified, since the codex has apparently lost its colophon page. 
VII. Jumādā I 534/1139. Single-volume codex in miniature square format $(8 \times 7 \mathrm{~cm})$, copied by Ahmad b. Ghalinduh in Almería. Madrid, National Library of Spain, Ms. REs $/ 272 .{ }^{48}$

VIII. 538/1143-1144. Single-volume codex in small square format $(18.2 \times$ $17.8 \mathrm{~cm}$ ), copied in Córdoba. Istanbul University Library, Ms. A $6755 .{ }^{49}$

IX. 556/116o-1161. Single-volume codex in small square format $(17 \times$ $16.5 \mathrm{~cm}$ ), copied by 'Abd Allāh b. Muḥammad b. 'Alī [Ibn Ghaț̣ūs] in Valencia. Present location unknown. ${ }^{50}$

X. 557/1161-1162. Single-volume codex in small square format $\left(18.5^{\times}\right.$ 17.5 cm), copied by 'Abd Allāh b. Muhammad b. 'Alī [Ibn Ghaț̣ūs] for the wazīr Abū Muḥammad 'Abd Allāh b. 'Abd al-Raḥmān b. 'Abd Allāh al-Madhhijī thumma al-Lawshī, in Valencia. Cairo National Library, Ms. 196 فصحف 51

XI. 558/1162-1163. Single-volume codex in small square format $(17.5 \times$ $16 \mathrm{~cm}$ ), copied and illuminated by 'Abd Allāh b. Muhammad b. 'Alī [Ibn Ghaț̣ūs] for Yāsīn b. Lubb b. Yāsīn, in Valencia. Tunis National Library, Ms. $18791 .^{52}$

XII. $\quad$ 559/1163-1164. Single-volume codex copied by Muhammad b. Mūsā b. Hizb Allāh in Valencia. Tetouan, Library of the Higher Institute, Ms. 1. ${ }^{53}$

XIII. 564/1168-1169. Single-volume codex in small square format $(16 \times$ $16.5 \mathrm{~cm}$ ), copied and illuminated by Muhammad b. 'Abd Allāh b. Muhammad [Ibn Ghațțus] in Valencia. Tunis National Library, Ms. $13727 .{ }^{54}$

XIV. Rajab 565/1170. Single-volume codex in small square format $(15 \times$ $15.7 \mathrm{~cm}$ ). Isle of Bute, Mount Stuart, Collection of the Marquess of Bute, Ms. 359,55

48 See above, note 25 .

49 See above, note 38.

50 This manuscript was auctioned twice: Oriental Manuscripts and Miniatures, Sotheby's, London, 30.4.1992, lot 336; Arts of the Islamic world, Sotheby's, London, 22.4.1999, lot 12. See also Dandel, "Ibn Ġațțūs", 13-15.

51 See above, note 6 .

52 See above, note 7 .

53 Sharīî, Khuțūt al-mașāhif, 270-271. Sharīî̀ examined the manuscript on the 6th of February 1973. Since then, it has probably been transferred to the Tetouan University Library (Kulliyyat Ușül al-Dīn), although I have so far been unable to locate it.

54 See above, note 12.

55 Mentioned in James, The Master Scribes, 89. The manuscript appears in the typewritten checklist compiled for the 4th Marquess of Bute, titled A Catalogue of Manuscripts in the Library at 5, Charlotte Square, Edinburgh (August 1935). 
XV. Ramaḍān 573/1178. Single-volume codex in small square format $(16.5 \times$ $15.5 \mathrm{~cm})$. Kuwait City, Tareq Rajab Museum, Inv. QUR.0059.TSR. ${ }^{56}$

XVI. 578/1182-1183. Single-volume codex in small square format $(18.2 \times$ $17 \mathrm{~cm}$ ), copied by Muḥammad b. 'Abd Allāh b. Muḥammad b. 'Alī b. Ghatțūs in Valencia. Istanbul University Library, Ms. A $6754 \cdot{ }^{57}$

XVII. Sha'bān $5 \mathbf{8}$ o/1184. First volume of a two-volume set in miniature square format $(10 \times 9.5 \mathrm{~cm})$, copied, vocalized, and illuminated by Muhammad b. 'Abd Allāh b. 'Alī al-Murrī. Dresden, Saxon State and University Library, Ms. Ea. $293 .{ }^{58}$

XVIII. Sha'bān $586 / 119$ o. Single-volume codex in small square format $(18 \times$ $15.5 \mathrm{~cm})$. Istanbul University Library, Ms. A $675^{2 .} .^{59}$

XIX. Muharram 587/1191. Single-volume codex in large rectangular format $(31.5 \times 26.2)$, copied by Muhammad b. Muhammad b. 'Alī b. Shu'ayb alAnșārī in Ceuta. Istanbul, Topkapı Palace Library, Ms. R. 27. ${ }^{60}$

XX. Safar 591/1195. Single-volume codex in small square format $(18.4 \times$ $17.2 \mathrm{~cm})$. Uppsala University Library, Ms. O. Vet. $77 .{ }^{61}$

XXI. Muharram 595/1198. Single-volume codex in small rectangular format $(21.5 \times 18 \mathrm{~cm})$. Médéa (Algeria), private collection, unknown shelf mark. ${ }^{62}$

XXII. Safar 595/1198. Second half of a single-volume codex in small square format, copied in Ceuta. Timbuktu, Library of the Ka'ti Foundation, unknown shelf mark. 63

XXIII. Muharram 596/1199. Single-volume codex in small square format $(16.5 \times 16.5 \mathrm{~cm})$, copied in Valencia. Istanbul, Topkapı Palace Library, Ms. R. 36.64

56 Tareq Rajab Museum (Kuwait: Tareq Rajab Museum, 1994), 27. The manuscript was previously kept in the Royal Library of Rabat, under the shelf mark 12609 (see Sharīfi, Khuțūt al-mașāhif, 275-277; Al-Andalus 1992, 308, no. 78).

57 Karatay, İstanbul Üniversitesi Kütüphanesi, I, 5, no. 14; Lings, The Quranic Art, 214-215, pls. 100-101; Dandel, "Ibn Ġațtūs", 18-19; Mustafa Derman, Nihad Çetin, The Art of Calligraphy in the Islamic Heritage (Istanbul: IRCICA, 1998), 204, no. 18.

$5^{8}$ See above, note 13.

59 Karatay, İstanbul Üniversitesi Kütüphanesi, I, 6, no. 15 .

6o Karatay, Topkapı Sarayı Müzesi, I, 83, no. 298; Derman \& Çetin, The Art of Calligraphy, 205, no. 21; Zeren Tanındı, "Başlangıcından Osmanlı'ya tezhip sanatı", in Hat ve tezhip sanatı, ed. Ali Rıza Özcan (Ankara: Kültür Bakanlığı Yayınları, 2015), 243-281: 249, fig. 4.

61 Tornberg, Codices arabici, 245, no. CCCLXX.

62 Sharīfi, Khuțūt al-mașāhif, 278-28o. I have so far been unable to locate this manuscript.

63 Miguel Camacho Ramírez, Fondo Kati: una biblioteca andalusí en Tombuctú (Seville: Junta de Andalucía, 2002), 46. I thank Professor Juan Pablo Arias Torres for having provided me with a few images of this manuscript.

64 Karatay, Topkapı Sarayı Müzesi, I, 84, no. 300. 
XxIV. 596/1199-120o. Single-volume codex in small square format $(17 \times$ $16 \mathrm{~cm}$ ), copied by Yūsuf b. 'Abd Allāh b. 'Abd al-Wāḥid b. Yūsuf b. Khaldūn for Aḥmad b. Muhammad b. Bīṭash al-Makhzūmī, in Valencia. London \& Geneva, Nasser D. Khalili Collection, Inv. QUR.318. ${ }^{65}$

Xxv. Dhū al-Qa'da 598/1202. Single-volume codex in small rectangular format $(20.5 \times 17.5 \mathrm{~cm})$. Istanbul, Topkapı Palace Library, Ms. R. $31{ }^{66}$

XXVI. Dhū al-Hijja 598/1202. Single-volume codex in medium rectangular format $(24.6 \times 22.5 \mathrm{~cm})$. Rabat, National Library of Morocco, Ms. 934 ج. ${ }^{67}$

XXVII. Jumādā II 599/1203. Single-volume codex in small rectangular format $(22.3 \times 18 \mathrm{~cm})$, copied by Muhammad al-Sharīshī and illuminated by Yūsuf b. ... (?) al-Mudhahhib, for Abū Ya'qūb, son of the Almohad caliph Abū 'Abd Allāh [al-Nāṣir], in Marrakesh. Istanbul, Topkapı Palace Library, Ms. R. $33 .{ }^{68}$

65 James, The master scribes, 92-95.

66 Karatay, Topkapı Sarayı Müzesi, I, 83, no. 296.

67 Sharīîi, Khuțūt al-mașăhif, 281-285. The results of the pigment analyses carried out on this manuscript have been presented in Patricia Roger, Malika Serghini, François Déroche, "Les matériaux de la couleur dans les manuscrits arabes de l' Occident musulman. Recherches sur la collection de la Bibliothèque générale et archives de Rabat et de la Bibliothèque nationale de France", Comptes rendus des séances de l'Académie des Inscriptions et BellesLettres 148 (April-June 2004), 799-83o.

68 Karatay, Topkapı Sarayı Müzesi, I, 83, no. 299. See also Lings, The Quranic Art, 216-219, pls. 102-103; Al-Andalus 1992, 309, no. 79. 